\title{
ГЕРМЕНЕВТИКА
}

\author{
Б.Л. Губман, К.В. Ануфриева
}

\section{ГЕРМЕНЕВТИКА П. РИКЁРА И АНАЛИТИЧЕСКАЯ ФИЛОСОФИЯ: ПРОБЛЕМА НАРРАТИВНОЙ САМОИДЕНТИЧНОСТИ ЛИЧНОСТИ}

\begin{abstract}
Аннотация. Предмет исследования, представленного в статье, решение проблемы нарративной самоидентичности личности в герменевтической феноменологии П. Рикёра, рассмотрение предложенной им платформы выявления единства тождественности и самости в процессе конструирования рефллексивного образа "я" в диалоге с аналитической философией. В этой перспективе должны быть выявлены особенности его полемики с различными вариантами объективистского рассмотрения личности и ее проявления в языковых актах, деятеля и действия в ракурсе семантики и прагматики, сложившимися в аналитической философии и приводящими к своеобразной ликвидации "Я" в реальности его уникального единства и становления во времени. В контексте статьи используется герменевтическая стратегия интерпретации рассматриваемой темы, применяется широкий спектр методов историко-философского анализа. Научная новизна исследования заключается, прежде всего, в том, что демонстрируется специфика конструктивного диалога, осуществляемого Рикёром с ведущими представителями современной аналитической философии в процессе создания им собственной концепции нарративной идентичности личности. Предложенная им программа синтеза аналитической философии и герменевтики рассматривается как вполне действенная и реализуемая в подходе к проблеме нарративной идентичности как выражения единства жизни личности.

Ключевые слова: личность, тождественность, самость, действие, событие, прагматика, семантика, нарративная идентичность, персонализм, герменевтика, аналитическая философия.

Review. The paper is focused on P. Ricoeur's interpretation of the personal narrative self-identity problem developed within the framework of his hermeneutical phenomenology and his understanding of the unity of identity and selfhood in the process of creating a reflexive image of 'Self' that appeared in the dialogue with analytical philosophy. Based on that, the authors of the article discuss particular features of Ricoeur's polemics with different versions of the objectivist approaches to personality and personality expression in language acts, actor and action from the point of view of semantics and pragmatics that were created within the framework of analytic philosophy and in fact led to some kind of liquidation of 'Self' desite the unique unity and timely existence of Self. In their research the authors have applied the hermeneutical strategy to interpreting the theme as well as a wide range of methods that are used in historical and philosophical analysis. The novelty of the research is caused, first and foremost, by the fact that the authors demonstrate peculiarities of the constructive dialogue that was established by Ricoeur with the leading representatives of contemporary analytical philosophy in the process of creating his own personal narrative self-identity doctrine. The program of the synthesis of analytical philosophy and hermeneutics offered by Ricoeur may be evaluated as a sufficiently valid and realizable approach when applied to the problem of the narrative identity as the expression of personal life unity.
\end{abstract}

Keywords: personality, identity, Self, selfhood, action, event, pragmatics, semantics, personalism, narrative identity, hermeneutics.

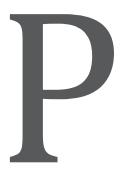

ефлексивное создание образа человеческого "Я", личностной самоидентичности всегда находилось в фокусе внимания П. Рикёра, который раскрывал различные грани этой проблемы на протяжении всего своего творческого пути. Устойчивая персоналистическая доминанта прослеживается в ходе эволюции его мысли от создания видения диалектики самосозидания личности через противостояние волевого и неподконтрольного воле начал к построению герменевтики возможных стратегий интерпретации человеческого “Я”, его становления во времени, которое запечатле- 


\section{Философия и культура 9(93) • 2015}

вается в повествовании о себе. В процессе создания собственного взгляда на проблему рефлексивного конституирования личностного “Я” Рикёр пришел к последовательному рассмотрению вопроса о границах объективации существования личности и средствах повествовательного выражения ею временной динамики целостности собственного жизненного пути. В этой перспективе становится вполне понятен его интерес к рассмотрению этой тематики не только континентальной европейской мыслью, но англо-американской аналитической философией. В поздний период творчества Рикёра установление своеобразной платформы синтеза между этими традициями прослеживается в качестве устойчивой доминанты его профессионального поиска. В данной связи несомненный интерес представляет выявление тех моментов возможного объединения потенциала континентальной европейской и англоамериканской аналитической философии, которые виделись Рикёру значимыми для осмысления проблемы нарративной самоидентичности личности.

\section{Стратегия анализа тождественности и самости «Я» личности: герменевтика и аналитическая философия}

Взгляд Рикёра на личностную самотождественность предполагает рассмотрение противоречивого многообразия процесса становления «Я». Проникновение в динамику его рефлексивного конституирования представляет достаточно сложную проблему прежде всего в силу необходимости фиксации особого рода предметности, которая радикально отличается от реалий объектно-вещного мира [1, с. 127]. Биение пульса человеческой субъективности, существование «Я» во времени, запечатлеваемое рефлексивным усилием и доступное феноменологическому описанию, требует одновременно и обнаружения того, что характеризует черты личностной тождественности, может быть предикативно выражено. Рефлексивная фиксация самотождественности неминуемо ставит проблему соотнесения «Я» и другого. Их инаковость оставляет все же возможность уподобления, перенесения определенных характеристик другого на мир «Я» в целях его описания. Этим, однако, не исчерпывается рефлексивное конституирование образа «Я», ибо оно предполагает картину жизненного пути личности, интерпретированную через момент настоящего. Опыт личностного существования неминуемо требует обращения к историческому опыту как достоянию коллективной памяти. Широта охвата проблемного поля динамики самосозидания «Я» личности побуждает Рикёра к рассмотрению не только европейской континентальной, но и англо-американской аналитической традиции.

Рикёр - теоретик, работающий в широком поле мыслительного наследия прошлого и современности, виртуозно синтезирующий весьма несхожие подходы к рассмотрению идентичности личности и рефлексивного формирования личностного «Я» [см.: 2, с. 273-287]. В его построениях прослеживается влияние Августина, Ф.-П.-Г. Мен де Бирана, Ф. Равессона, Ж. Набера, Ф. Ницше, А. Бергсона, Э. Гуссерля, 3. Фрейда, Г. Марселя, К. Ясперса, М. Хайдеггера, Х.Г. Гадамера, Э. Левинаса и других авторов, выражающих дух континентальной европейской традиции. Одновременно в произведениях Рикёра постоянно присутствуют ссылки на круг идей Л. Витгенштейна, Г. Райла, Д. Остина, П. Стросона, Д. Сёрля, А. Данто и иных видных представителей аналитической философии. Синтез двух мыслительных традиций представляются Рикёру актуальной задачей современной философии, позволяющей создать новый способ рассмотрения теоретико-мировоззренческих проблем. К их числу прежде всего относится тематическое поле, связанное с изучением рефлексивной самоидентичности личности, становящееся доминирующим в его позднем творчестве. Это обстоятельство отчетливо обнаруживается в его трехтомном произведении “Время и рассказ”, в книгах “Я-сам как другой”, “История, Память, Забвение” и других произведениях. Характерно, что сам стиль рассмотрения проблемы рефлексивной идентичности личности на позднем витке его творчества несет на себе отпечаток способа теоретизирования, укоренившегося в англо-американской аналитической философии и связанного с постоянной работой по прояснению ткани языка, в котором представлена та или иная предметность. Подобная стилистика отнюдь не означает отречения от герменевтической установки, а, напротив, как представляется, глобализирует ее притязания, уточняет ее инструментарий и придает ей новые возможности.

Приступая к анализу различных вариантов видения рефлексивной самоидентичности “Я”, Рикёр прежде всего пытается сформулировать возможность сочетания в его едином образе тождественности и самости, показывая, что их единение составляет известную проблему. Картезианское Cogito, на взгляд Рикёра, несет в себе возможность лишь “точечной”, “трансисторической” идентично- 
сти того же самого через разнообразие операций “Я" [3, с. 22]. Оно по сути снимает альтернативу постоянства и изменения во времени, получая гарантию собственного существования через признание бесконечности Абсолюта. Чтобы избежать психологизма, размышления Декарта должны были претерпеть трансформацию в ключе трансцендентализма Канта, и только тогда “я мыслю” станет определять все представления. Однако при этом, по Рикёру, подобный философский ход был оплачен ценой отказа от персоналистического диалога "Я" и “Ты”, идентичности исторической личности, ее ответственности. Яростным и последовательным оппонентом Декарта выступил Ф. Ницше, который, как справедливо констатирует Рикёр, показал невозможность существования чистой мысли вне её языковой формы, риторических конструкций [3, c. 27]. Принимая ницшеанскую аргументацию, Рикёр говорит о ценности идеи немецкого философа об интерпретативном характере не только внешнего, но и внутреннего опыта субъекта. В свете полемики Ницше против Декарта вырисовывается необходимость герменевтической стратегии интерпретации личностной самости.

Герменевтика, понимаемая в философском ключе, по Рикёру, безусловно должна быть нацелена на фиксацию онтологических оснований рефлексивного самосозидания “Я” личности. Рассматривая своеобразное выстраивание образа “Я”, французский автор замечает, что именно язык позволяет нам понять сам ход его создания через косвенную рефлексию относящегося к его речевому действию, сочетанию самости и тождественности, самости и инаковости. Через язык "высвечиваются”, и в этом с ним можно полностью согласиться, характеристики носителя акта действия, говорения, повествования о себе, моральной реакции на происходящее. Именно поэтому Рикёр полагает вполне оправданным заключить союз герменевтики с аналитической философией с целью последовательного продвижения к воспроизведению целостности рефлексивного конструирования образа “Я”. “Обращение к анализу в смысле, какой придает этому термину аналитическая философия, - констатирует он, - представляет собой цену, которую следует заплатить за герменевтику, характеризующуюся косвенным статусом позиции “Я”” [3, с. 33]. Именно этот косвенный путь представляется ему наиболее последовательным с точки зрения раскрытия имманентного механизма конституирования личностного “Я”.
Аналитическая философия позволяет прежде всего взглянуть на проблему в ключе семантики и прагматики, ибо надлежит выяснить подразумеваемое в референциальном смысле под личностью и специфику ее представленности в коммуникации. Поскольку аналитическая мысль рассматривает речевые акты как специфический вид деятельности, эта тематика составляет следующий, второй шаг декларируемого Рикёром синтеза. Третью стадию движения в этом направлении составляет тема нарративной идентичности личности, ее самораскрытия через целостное повествование о себе. И после этого становится возможным осуществление четвертого этапа рассмотрения этической и моральной детерминации деятельности в процессе рефлексивного построения образа “Я" и движения к завершающей стадии онтологического исследования темы.

При построении рефлексивного образа личностного "Я" возникает проблема достоверности такового, решаемая Рикёром при помощи обращения к критерию, именуемому им “аттестация". Аттестация, на взгляд Рикёра, определяет тип достоверности, на который способна претендовать герменевтика, преодолевая противоречие между картезианским взглядом, предполагающим возможности интеллектуально очевидного для чистой мыслительной активности сознания, и его ницшеанским тотальным отрицанием. Аттестация противостоит научному понятию “эпистемы”, предполагающему финальное и самообосновывающееся знание, но это и не докса (вера). “Тем самым, - заключает Рикёр, - как показывает этимология, аттестация сближается со свидетельством, в той мере, в какой мы верим именно в слово свидетельства" [3, с.33]. Как базирующаяся на феномене доверия аттестация играет роль высшей эпистемической инстанции герменевтического исследования тождественности и самотождественности “Я”. Она выступает доверием к способности субъекта говорить, делать, рассматривать себя как персонаж рассказа и как морально ответственное за собственные деяния лицо. Именно поэтому относительно герменевтики “Я-сам”, реализующейся в конечной инстанции в способности делать и претерпевать действие, аттестация может являться на лингвистическом, практическом, нарративном и прескриптивном уровнях.

Рассуждая о тождественности “Я”, по мысли Рикёра, аналитику следует, прежде всего, обратиться к ресурсам семантического подхода. Логика и эпистемология, как уточняет он, работают 
при рассмотрении сингулярностей с операторами индивидуализации: определенными описаниями, именами собственными и так называемыми шифтерами (личные и указательные местоимения, наречия времени, глагольные времена и т.д.). Именно в пределах семантического подхода становится возможным выявить путем идентифицирующей референции то индивидуальное образование, которое можно обозначить как личность. Приступая к решению этой задачи, предполагающей объективирование личности среди индивидуальных образований данного нам в языке мира, Рикёр обращается к наследию П. Стросона.

Проблема индивидуации - одна из центральных в дескриптивной метафизике Стросона. Мир, данный нам в обыденном языке, представим, прежде всего, как состоящий из индивидуальностей, и личность как нечто самотождественное и неповторимое принадлежит к их числу, также как и тела. Объектно-вещное видение индивидуальностей в мире языка, подразумевает, по Стросону, возможность фиксации их тождественности в границах пространства и времени. Британский автор утверждает, что "система пространственно-временных отношений обладает специфическим охватом и проникновением, которые делают ее уникальной для создания рамок, внутри которых мы можем организовать нашу индивидуализирующую мысль относительно особого" [4, р. 25]. Каждое индивидуальное образование обладает местом в этой системе или принадлежит общности, члены которой могут быть идентифицированы только через отнесение к индивидуальным образованиям иного рода, которые существуют в ней. При этом, каждое индивидуальное образование, существующее в этой системе занимает в ней уникальное место. При описании чисто индивидуальных образований, по Стросону, используются имена собственные, имена мест, даты, которые нужны для повествования о них. Именно так рисуется им процесс создания схем описания индивидуального, хотя никогда не может быть полной уверенности в их неповторимости. Концептуальный схематизм опознания индивидуального образования в пространственно-временных обстоятельствах одновременно оставляет вопрос о значимости позиции субъекта, судящего о его тождественности. Кроме того, в стросоновской трактовке индивидуации возникают и иные проблемы, например, вопрос о тождественности индивидуального в несхожих пространственных обстоятельствах.
Очевидно, что дескриптивная метафизика Стросона многим обязана кантовской эпистемологии, в особенности, учению об априоризме форм чувственности, а также концепции схематизма продуктивного воображения, что британский философ и не думает скрывать [4, p. 62]. Личность как особое, наряду с телом, индивидуальное образование также, по его мнению, может быть запечатлена особой схемой существования в пространственновременных координатах. Рассуждая о специфике личности, Стросон портретирует ее в картезианском духе как обладающую двумя полярными ипостасями существования - телом и миром индивидуального опыта. В этой связи возникают многочисленные трудности, связанные с возможностью описать опыт личности как сугубо индивидуальный [4, р. 100]. Не меньшие проблемы сулит и попытка охарактеризовать чужой опыт, ибо и здесь возможна утеря его индивидуальности. Таковы по сути дилеммы проникновения в индивидуальный опыт “Я” и “Другого” в границах дескриптивной метафизики, тотально объективирующей не только индивидуальные тела, но и личности.

Рикёр полагает вполне допустимым воспользоваться в качестве отправной точки своего дальнейшего теоретизирования стросоновским истолкованием личности как особого, наряду с телами, типа базовых индивидуальных образований мира. Одновременно он считает важным отметить, что при подобном подходе "личность есть, скорее, одна из "вещей”, о которых мы говорим, нежели говорящий субъект” [3, с. 49]. Эта тема приобретает еще более развернутое звучание при переходе Рикёра к анализу ресурсов и ограничений исследования личностной идентичности в ключе лингвистической прагматики, а затем и семантики действия.

Прагматика выделяет собственный ракурс видения языка, являясь теорией его употребления в определенных контекстах, предполагающих коммуникативное взаимодействие с другими людьми. “Я” личности прорисовывается здесь через ее высказывания в контексте коммуникативной практики, как поясняет Рикёр, в ситуации беседы. Одиночество “Я” оказывается сменяемым его контактами с другими людьми, опосредованными языком. Поскольку же прагматика не просто опирается на эмпирическое описание коммуникативного взаимодействия, но и выясняет условия возможности такового, то она, по мнению Рикёра, исходит из трансцендентальной установки в понимании речевой практики [3, с. 60]. Очевидно, что 
сочинения теоретиков актов дискурса от Д. Остина до Д. Серля читаются им, исходя из презумпции определенного языкового априоризма.

Продолжая развитие философии обыденного языка, основоположником которой был Витгенштейн, Остин, как известно, обратил особое внимание на то обстоятельство, что язык не только описывает мир, но и содержит перформативный потенциал, фиксируя действие [5, р. 8-9]. Предложения, используемые в коммуникативной практике не только означают определенные реалии, но и выражают действие, а также ориентированы на достижение цели говорящего в его влиянии на окружающих (локутивные, иллокутивные, перлокутивные акты). Серль объяснил перформативный потенциал языка, ссылаясь на интенциональность действия как общее свойство животных и людей. “Язык производен от интенциональности, а не наоборот” [6, p. 5], - заключает он. Комментируя достижения теории речевых актов, Рикёр полагает, что “герменевтика должна обращаться не только к лингвистике - даже когда она понимается как лингвистика дискурса в противоположность лингвистике языка, - но также к теории речевых актов как они представлены в работах Остина и Серля" [7, p. 134]. В трактовке Рикёра в теории речевых актов коммуникативная стратегия позволяет обеспечить продвижение к самости говорящего в свете обращения к инаковости партнера, ибо их беседа выступает как своеобразный “обмен интенциональностями".

Индикатор личностного “Я” в акте высказывания выходит на первый план в отличие от референциального подхода, группируя вокруг себя все иные. Однако сам подобный “дрейф” к рефлексивному осознанию личностной самости оказывается, по справедливой констатации Рикёра, в речевом акте парадоксальным образом неполным, ибо местоимение "я" полностью не привязано в нем к неповторимой личности. Ссылаясь на размышления Витгенштейна, Рикёр формулирует апорию согласно которой исключительная точка зрения на мир, выражаемая говорящим, есть предел и не принадлежит этому миру, но при осуществлении высказывания "Я" говорящего начинает мыслиться в нем, ибо может быть обозначено именем собственным [3, с. 71]. Итак, говорящий есть и одновременно не есть предел мира. Для разрешения этой апории Рикёр полагает необходимым совместить пути референции и рефлексивности высказывания, хотя подобный мыслительный демарш вряд ли осуществим: рефлексивное “Я" можно просто мыслить как находящееся в объективированной индивидуальности личности, телесно присутствующей в мире, но это не снимает их полярности.

Обращение к теории действия, по Рикёру, также приводит к сложным поискам путей его теоретического описания одновременно с рассмотрением агента, которому принадлежит его авторство. Здесь вновь возникает ранее зафиксированное противоречие между семантикой действия и прагматическим ракурсом его рассмотрения, заставляющим вспомнить о деятеле его совершившем. Рассмотрение этой проблематики представляется Рикёру невозможным без обращения к теоретическим штудиям А. Данто, Д. Дэвидсона, А.Д. Мелдена, С.Т. Хэмпшира, Э. Энском и других авторов, анализировавших эти вопросы в ключе аналитической философской традиции. В контексте своих размышлений о содержании их идей Рикёр, как и прежде, исходит из способности философской рефлексии раскрыть априорную структуру описания действия и его автора. Это, в его понимании, является необходимым шагом на пути понимания конституирования различных практик, в которые вовлечена личность, способная рефлексивно выстраивать повествование о собственном "Я".

Действие в трактовке Рикёра раскрывается как обладающее определенной структурой описания в перспективе семантического анализа, объективирующего смысл совершенного [8, р. 140-163]. Прежде всего, он раскрывает базисные полярности семантики действия, обстоятельно рассмотренные в аналитической философии, хотя и не забывает отметить, что его глубинно-онтологические характеристики были выявлены М. Хайдеггером и Х. Арендт. В границах аналитической философии действия проводится серьезное исследование различий между произошедшим событием и порождающим его действием, причинностью и мотивацией, которая в психологическом плане может вести к его осуществлению. А. Данто, например, специально рассматривает различие базового описания события, истина которого не предполагает свершение какого-либо иного события, и интерпретативных небазовых дескрипций, в числе которых параллельно с рядом телесной причинности могут фигурировать психологические факторы и, прежде всего, волеизъявление предполагаемого агента действия [9, р. 55]. Полагая, что понятийная сеть действия имеет тот же трансцендентальный статус, что и выявленные Стросоном базисные индивидуальные образования, Рикёр выделяет по- 


\section{Философия и культура 9(93) • 2015}

лярности двух типов языковых игр, порождающих различные дискурсивные миры: с одной стороны, действия и его мотива, а с другой, события и его причины [3, с.87]. Вслед за этим он обращается к анализу интенциональности, семантики действия и онтологии события, показывая, что дальнейший шаг в анализе действия предполагает постановку проблемы приписывания такового субъекту в перспективе прагматики.

Ракурс прагматического рассмотрения действия возвращает к его принадлежности субъекту, совершившему таковое. Как показывает Рикёр, эта проблематика достаточно продуктивно обсуждается уже Аристотелем, увидевшим значимость предпочтительного выбора действия, соединения этического принципа его свершения и самости “Я". Он усматривает определенное сходство между способом рассмотрения этой проблемы, предложенным Аристотелем, и ее видением в “Индивидах" Стросона. Соединение субъекта и избранного им сценария действия, в понимании Рикёра, порождает определенные проблемы осмысления их сосуществования, запечатлеваемы в апориях приписывания - аскрипции.

Первая из характеризуемых Рикёром апорий связана с уже упоминавшимся утверждением Стросона о возможности приписывания уникально неповторимым “Я” и “Другому” одинаковых практических предикатов, описывающих психологически смысловое содержание действия. Рикёр поясняет, что “"психическое” представляет собой набор психических предикатов, каковыми располагает та или иная культура" [3, с. 124]. По сути, индивидуальноличностному, как предупреждает он, в этой ситуации грозит нивелировка описания в понятийной сети общего и особенного. Им ставится важная теоретическая проблема возможности характеристики индивидуально-неповторимого действия, совершаемого уникальной личность, в словаре наличного языка, позволяющего раскрыть психологическое и культурно-смысловое содержание такового, приобретающая сразу же герменевтическое наполнение. Она заставляет задуматься о том, что фиксация самости “Я” и уникальности его деяний предполагает выход за рамки синхронии в ситуативно-временное, диахронное измерение при его описании.

Вторая апория, согласно Рикёру, сводится к тому, что приписывание определенных характеристик субъекту и действию, им совершаемому, оказывается не просто описанием, но и нормативным предписанием. Деятель, поименованный опреде- ленным образом, оказывается осуществляющим свои деяния сообразно с определенными нормативными правилами и оказывается изначально ответственным за них. Стало быть, обращаясь к наследию философской мысли от Аристотеля до Х.Л.А. Харта, можно констатировать, что приписывание таит в себе предписание, а обыденный язык влечет за собой моральный и юридический дискурс. Правда, Рикёр, все же полагает, что моральное и юридическое вменение относится к практикам, слагающимся из многих действий [3, с. 127]. Индивидуальные же действия - сфера простого приписывания, где все же присутствует норма и ответственность. Если продолжить размышления Рикёра по этому поводу, то в этом контексте находит продолжение и тема герменевтической разгадки смыслового содержания аскрипции-прескрипции в контексте времени и создания рефлексивного образа “Я”.

Наконец, третья выдвигаемая Рикёром апория приписывания действия субъекту такового имеет откровенно кантовские корни и заключается в непреодолимо дуальной противоположности естественной причинности, обнаружимой в мире явлений, и свободной причинности, принадлежащей к умопостигаемому миру. "Причинность по законам природы есть не единственная причинность, из которой можно вывести все явления в мире. Для объяснения явлений необходимо еще допустить свободную причинность (Causalitat durch Freiheit)" [10, с. 418], - писал Кант. Допущение свободы как источника действия, по Рикёру, требует возвращения к аристотелевскому пониманию действующей причинности, изгнанному из философского дискурса успехами механистически ориентированной классической науки Нового времени. “Только в этой феноменологии "я могу" и в примыкающей к ней онтологии собственного тела статус исходного факта, соединенного со способностью к действию, может быть окончательно установлен" [3, с. 139]. Допущение спонтанности свободы личности как финального источника действия, в понимании Рикёра, вполне примиримо с описанием естественной причинной цепи порождения событий в контексте такового, но только в перспективе наррации личной идентичности.

Таким образом, апории приписывания субъекту действия приводят к пониманию самости “Я” личности как итога свободы. Тождественность личности обретает дополнение в ее самости, укорененной в свободе, что способствует дальнейшей постановке вопроса о возможности объединения 
двух этих перспектив видения “Я”. Она обнаруживается на основе стратегии осмысления нарративной самоидентичности личности, отмеченной новым витком синтеза наследия аналитической философии и герменевтики.

\section{Время жизни и нарративная самоидентичность личности}

Определение личности в границах идентифицирующей референции семантики и деятеля в перспективе прагматики, равно как и применение ресурсов семантического и прагматического анализа к изучению действия и его субъекта, как справедливо полагает Рикёр, в одинаковой мере обладают существенным недостатком, не принимая в расчет, что самосозидающее «Я» не только существует во времени, но и является «собственной историей» [3, с. 142]. Тождественность и самость личностного «Я» должны поэтому предстать в рассказе о его жизненном пути в его временной динамике. При этом, личность оказывается одновременно принадлежащей истории и обладающей рефлексивно осмысленной историей своего жизненного пути, запечатленной в рассказе.

Во «Времени и рассказе» Рикёр ставит вопрос о нарративной самоидентичности личности следующим образом: «Но каково основание постоянства имени собственного? Что оправдывает принятие субъекта действия, означенного, таким образом, своим именем, за того же самого на протяжении жизни, которая продолжается от рождения до смерти? Ответом может быть только: нарратив. Ответом на вопрос «кто?», как решительно утверждала Х. Арендт, является рассказ об истории жизни. Рассказанная история говорит о том, кто стоит за действием. Идентичность «кто» не есть, стало быть, сама по себе что-либо иное, нежели нарративная идентичность» [11, р. 355]. Повествование о жизни личности оказывается тем самым средством обеспечения единства тождественности и самости в ее описании. Характерно, что в данной связи Рикёр ссылается на понимание наррации как воспроизведение опыта жизни во времени, предложенное Арендт. Именно представления Хайдеггера и Арендт об онтологии человеческого существования во времени лежат в основе дальнейших размышлений Рикёра о нарративной самоидентичности личности. Специфика его понимания этого тематического поля во многом определяется также и общей установкой, сообразно с которой наррацию личной идентичности в принципе следует рассматривать как синтетической вариант исторического и художественного повествования [11, р. 279]. Конструирование истории жизни на фоне истории человеческого сообщества и создание повествования, использующего ресурс художественного варианта творческого воображения, органически сочетаются при создании рассказа о жизни личности. Кроме того, Рикёр полагает, что рассказ выполняет роль своеобразного опосредующего звена между описанием и предписанием, поскольку каждый момент этой триады будет по-своему характеризовать «Я» и действие. Наррация рассматривает жизнь личности в связи и последовательности ее включенности в различные состояния и практики, а, следовательно, содержит имманентно отношение к области этики. Это дает Рикёру основание для утверждения о несуществовании этически нейтральных повествований о жизни «Я».

Возвращаясь к сюжету о личной идентичности в нарративном контексте, Рикёр полагает важным подчеркнуть, что теперь эта тема должна обсуждаться в диахронной плоскости времени жизни. Это в равной степени относится к количественным и качественным характеристикам повествовательной идентичности. Разговор о количественной характеристике связан в данном аналитическом ракурсе с рассуждением о единстве или множественности личности в процессе ее жизненной карьеры. Одновременно возникает и проблема качественной тождественности личности, сопряженной с ее наличным бытием, явленным другим людям, способным к ее опознанию. Ведь иногда, как верно замечает Рикёр, возникает проблема опознания той или иной личности в ходе судебного разбирательства, связанного с обнаружением определенных противоправных действий. «Вот почему от угрозы, которую время представляет для идентичности, можно по-настоящему избавиться, только если на основании подобия и непрерывного постоянства изменения мы сможем сформулировать принцип перманентности во времени» [3, c. 147]. Стало быть, сохранение определенных постоянных качественных характеристик, а также преемственности в стадиях развития личности на различных этапах ее жизненного пути будут свидетельством ее единичности, доступной повествовательному описанию. Проблема опознания личности как сохраняющей тождество во времени, однако, не оказывается снятой путем допущения этого принципа и требует прояснения инструмен- 


\section{Философия и культура 9(93) • 2015}

тария концептуальной фиксации интересующей нас предметности.

Поскольку Рикёр все время апеллирует к кантовской категориальной платформе, то он заключает, что не только количество и качество, но и категория субстанции могут быть применены для обнаружения фиксации тождественного в перспективе поиска постоянства во времени. Вся трудность применения субстанциальных представлений к вопросу о тождественности личности во времени заключается, однако, в том, что эта предметность в ракурсе снятия объектно-вещного ее рассмотрения не поддается субстанциальному описанию. Постоянство личностной реальности во времени, если не следовать стросоновскому пониманию схемы ее существования как особой вещи среди других партикулярностей, должно фиксироваться феноменологически путем проникновения в духовно-личностный мир. Именно поэтому Рикёр, отказываясь от субстратно-субстанциального анализа личностной тождественности во времени, говорит о возможности фиксации таковой двумя дескриптивными и одновременно символическими терминами: характер и сдерживаемое слово. Постоянство характера, в его понимании, наиболее полно свидетельствует о почти полном единении проблематики тождественности и самости, в то время как верность слову, напротив, приводит к их противопоставлению.

Под характером Рикёр подразумевает «совокупность отличительных признаков, позволяющих повторно идентифицировать человеческого индивида как самотождественного» [3, с. 148]. В дескриптивном плане характер видится ему как полностью вбирающий количественную и качественную идентичность, непрерывное постоянство и постоянство во времени, что одновременно ведет к обозначению эмблематической тождественности личности. В понимания характера Рикёром в поздний период его творчества и его ранней трактовкой в «Волевом и неволевом» имеются, чего не скрывает и он сам, существенные расхождения. В границах раннего варианта философии воли он понимал под характером «абсолютно неволевое» начало личности. «Мой характер ситуативно обусловливает меня, - писал Рикёр, - отливает меня в индивидуальноть. Я уступаю себе как данный индивидуум» [12, р. 368]. В этой своей фактичности и даже фатальности характер рисовался ему связанным с бессознательным и жизненной необходимостью, заданной рождением [12, р. 410]. Позднее в “Человеке погрешимом" он говорит о характере как определенном конечной перспективой человеческого существования, связанной с открытостью миру. В дальнейшем в его понимание характера приходит тема временного измерения, понимания такового как “длительных предрасположенностей, по которым мы узнаем личность” [3, с. 151]. Рикёр полагает важным отметить связь характера и привычки, а также его сопряженность с совокупностью приобретенных идентификаций путем соотнесения себя с ценностями, нормами, идеалами, моделями, героями. Присутствие в характере историчности позволяет Рикёру говорить о его нарративном измерении. Г. Райл писал о диспозиционном характере фиксации явлений сознания, фиксированных в языке и связанных с деятельностью субъекта [13, с. 129]. Его теоретические идеи Рикёр рассматривает как сопряженные с эволюцией собственных представлений об историческом измерении трансформации характера личности на базе повествования.

В модели сдержанного слова Рикёр видит эмблематическую фигуру идентичности, говорящую о сохранении “Я" и противостоящую характеру. Ссылаясь на экзистенциальную аналитику Хайдеггера, он рассматривает верность обещанию как выбор, брошенный времени, и отрицание изменения при сохранении “Я" [3, с. 154]. Нарративная идентичность при такой постановке вопроса простирается между двумя пределами постоянства во времени - нижним пределом упорства характера, предполагающим совпадение “тождественности” и “самости”, и верхним пределом сохранением "Я” в обещании, когда действует лишь “самость".

Важной темой в данной связи становится взаимосвязь памяти и личной идентичности. Именно память, по мысли Рикёра, служит основанием нарративной идентичности личности, позволяя создать повествование о ее жизненном пути во времени. Рассуждая специфике памяти в своих поздних произведениях, он обращается к истории европейской философии, представители которой обозначили принципиальные направления ее феноменологического анализа. Уже Платона положил начало феноменологического описания работы памяти, заговорив о возможности представления в настоящем отсутствующей вещи, а различие простого воспоминания и вызывания в памяти было проанализировано Аристотелем [14, c. 41]. Августин выявил специфику памяти как сопряженной с существованием человека во време- 
ни. Большое значение придает Рикёр изучению механизма памяти Д. Локком, который понял не только её ассоциативный, но и рефлексивный механизм, действующий при построении образа личностной идентичности. На этой базе он подошел к раскрытию парадоксов личностной идентичности. Юм обнаружил связь механизмов памяти, воображения и опыта в конструировании идентичности личности. Продуктивный анализ работы памяти в создания образа “Я" содержится в феноменологии Э. Гуссерля, а также в разграничении А. Бергсоном памяти-привычки и памяти-воспоминания [14, c. 48]. Обеспечивая возможность идентичности личности, индивидуальная память видится Рикёру аккумулирующей индивидуальный опыта, находящийся в нерасторжимом единстве с коллективным опытом и памятью. Это обстоятельство было зафиксировано М. Хайдеггером, Х. Арендт, Х.-Г. Гадамером, Л. Витгенштейном и другими теоретиками.

Рассмотрение памяти как основополагающего свойства сознания, обеспечивающего единство опыта пребывания личности во времени, запечатлевающегося в нарративной идентичности, ведется Рикёром в полемике с Д. Парфитом, отвергающим с философских позиций значимость проблематики персональной тождественности [15, p. 285]. В своем фундаментальном и имевшем широкую популярность труде "Основания и личности" этот британский автор исходит из редукционистской посылки существовании лишь объективно фиксируемых вещных и психических свойств и состояний, а также связей между ними, позволяющих охарактеризовать любые образования, в том числе и личности. Такого рода подход видится Парфиту не дающим оснований для разговора о личностной идентичности. Он аргументирует свой взгляд, прибегая к так называемым “озадачивающим примерам". Так, допущение возможности телепортации личности заставляет задуматься о том, будут ли тождественны изначально существующий индивид и его перемещенный, скажем, на Марс вариант. Мы не можем обрести основания тождественности телепортируемой личности даже при полном сходстве перемещаемого и перемещенного в пространстве и времени индивидов, ибо не можем сказать, кто из них аутентичен, каковы критерии подобной констатации, ее эталон, правомерно ли вообще говорить о их тождестве, если имели место физическая кончина и рождение вновь, и т.д. Что касается позиции Рикёра, сталкивающегося с подобными аналитическими аргументами, то он склонен полагать, что наличие осознания произведенного во времени действия по телепортации у подвергшейся ей личности дает возможность выхода из лабиринта противоречий Парфита [3, с. 168]. Ответом на парадоксы его "озадачивающих примеров", по Рикёру, должно стать обращение к модели нарративной самоидентичности личности, предполагающей допущение постоянного самоописания ее жизненного пути во времени с точки зрения настоящего.

Рассуждая о теории повествования во “Времени и рассказе", Рикёр подчеркивал, что она становится возможной в перспективе синтеза, намеченного в наследии Августина, которое позволяет увидеть в нем воспроизведение экзистенциального опыта пребывания во времени, и в трудах Аристотеля, уделившего впервые особое внимание способам его языковой фиксации, предполагающим осознание значимости интриги [16, с. 13]. Рассказанные истории так или иначе связаны с интерпретацией мира, в котором живет их автор совместно с другими людьми. Они направлены на воспроизведение "жизненного мира”, в котором пребывает рассказчик, облечены в особую языковую форму повествования и ориентированы на потенциального читателя или слушателя. Именно в этом состоит основной пафос учения Рикёра о трех фазах "мимесиса" как "подражания действию”, сопровождающих герменевтическое интерпретативно-круговое освоение мира в рассказе [16, с. 90-91]. Любое повествование предстает связанным с интерсубъективной структурой не только его построения, но и освоения во времени. Однако у истории, рассказанной о себе, позволяющей конструировать образ самотождественности "Я", имеются и существенные отличия, становящиеся предметом анализа Рикёра.

Обращаясь к наследию В. Дильтея, Рикёр говорит, что нарративная самоидентичность нацелена на повествование о единстве конкретной жизни. Значит, нарративная идентичность сфокусирована всегда на центральном персонаже - на "Я" автора, ведущего рассказ. Она - результат истории, рассказанной о себе. При этом, как представляется Рикёру, интрига, понимавшаяся Аристотелем как “способ упорядочивания фактов" повествования, становится на службу персонажу. Он справедливо полагает, что при этом "идентичность персонажа понимается через перенесение в нее операции завязывания интриги..." [3, с. 175]. Если учесть это обстоятельство, то тогда обеспечение ею традиционных функций завершенности, целостности и надлежащей протяженности повествования ока- 


\section{Философия и культура 9(93) • 2015}

зывается служащей в этом варианте именно задаче раскрытия идентичности персонажа, от лица которого ведется самоописание.

Нарративная конфигурация обретения идентичности предполагает связь разнородного во времени повествования. Динамическая нарративная идентичность примиряет, по Рикёру, даже категории тождества и различия, которые Локк видел радикально противостоящими друг другу. В ее контексте устанавливается реальная связь между действием и персонажем, ибо интрига связывает воедино рассказанное и динамику характера. Ссылаясь на исследование Ф. Кермоуда [см.: 17], Рикёр констатирует органику взаимосвязи характера личности и действия в повествовании о себе.

Противоположности субъекта и действия, а также полярности действия и его мотива, события и его причины, зафиксированные аналитической философией в плоскости семантического и прагматического рассмотрения, действительно оказываются преодоленными в целостности повествования о себе, рисующем самотождественность персонажа на протяжении его жизненной карьеры. В контексте наррации о себе, предполагающей в перспективе интриги переплетение процессуального описания действия и деятеля, преодолеваются и выделяемые аналитически апории приписывания. Конечно же, сами мыслительные проблемы, акцентируемые ими, никуда не исчезают, но, как верно отмечает Рикёр, в рассказе о себе одновременно содержатся сведения о том, кто и что сделал, почему и как это произошло во временной динамике. В повествовании психические предикаты обязательно приписываются деятелям, а о действиях судят, указывая на мотивы. Дескриптивный и прескриптивно-нормативный моменты шагают рука об руку. В наррации снимается и кантовское противопоставление свободы и причинно-следственных связей. “Повествование разрешает антиномию на свой лад - с одной стороны, наделяя персонаж инициативой, то есть способностью давать начало серии событий без того, чтобы это начало представляло собой абсолютное начало, начало времени; с другой, наделяя рассказчика как такового способностью определять начало, средину и конец действия" [3, с. 180]. В повествовании о себе автор предстает свободным творцом действия, хотя и испытывает воздействие других людей, а приходящее событие вырисовывается в его целостном видении жизненного пути человека, временной тотальности такового и может обрести статус слу- чайности или нарративно необходимого. Именно в этом ракурсе Рикёру видится ответ аналитической философии в ключе герменевтического рассмотрения нарративной идентичности.

Персонаж рисуется Рикёром свободным автором повествования о своей жизни с позиций настоящего и одновременно плодом интриги собственной наррации. “Повествование созидает идентичность персонажа, которую мы можем назвать его нарративной идентичностью, строя идентичность рассказываемой истории. И как раз идентичность истории создает идентичность персонажа" [3, с. 180]. Именно поэтому, по верному замечанию Рикёра, повествование, связываемое им с деятельностью понимаемого в кантовском варианте продуктивного воображения, выполняет посредническую функцию между полюсами тождественности характера и самости сохранения “Я” во времени. В силу этого обстоятельства, и литература тому свидетельством, повествование, а, значит, и личностная самоидентичность могут иметь неограниченное количество вариантов воплощения. В предельных примерах литературного стирания тождественности характера, движения к утрате идентичности, подобных представленным в романе Р. Музиля “Человек без свойств”, по Рикёру, вполне допустимо сопоставление с утверждающими ту же идею “озадачивающими примерами” Парфита.

Нарративная идентичность предполагает существование субъекта во взаимодействии с другими людьми, его вовлечение во многообразие общественных практик, описание которых одновременно запечатлевает нормативный компонент их регуляции. Практическое поле, попадающее в область повествования, стало быть, расширяется за рамки индивидуального действия. Говоря о специфике организации практик, Рикёр вспоминает теорию их создания из комплексов действий А. Данто, концепции удлиненной цепи действий Э. Энском и комбинации физической причинности и интенциональных элементов Г. фон Вригта, а также идеи Д. Серля о конституировании иллокутивных актов по определенным правилам. В конечной же инстанции он приходит к веберианскому истолкованию практики как “социального действия", предполагающего, что деятель ориентирован на действия других и совместное полагание смысла в совершаемом. “Соотноситься с другими деятелями, учитывать их поведение - вот наиболее обобщенное и нейтральное выражение, которое может покрыть собой отношение взаимодействия, встреча- 
емое нами на уровне тех единиц действия, какими являются практики" [3, с. 189]. Взаимодействие в различных видах практик от науки, искусства, ремесел до наставничества или ученичества предполагает определенные отношения упорядоченные правилами. Описание Рикёром практик как “историзированного” взаимодействия, имеющего игровой характер, позволяет говорить не только о влиянии на его воззрения теории языковых игр Витгенштейна, но и о специфической ассимиляции им трактовки игрового характера герменевтического опыта Гадамера.

Нарративная самоидентичность рождается в синтетическом соединении во времени повествования индивидуального и коллективного опыта, описания собственного действия, активности и претерпевания действия со стороны других в поле практик, осваиваемого смыслового содержания исторического опыта. Именно поэтому Рикёр говорит о близости собственного видения нарративной самоидентичности концепции А. Макинтайра. В развиваемой им концепции "нарративного единства жизни” этот автор, подобно Рикёру, выступает против фактического отрицания значимости личностной самоидентичности как тенденции современной западной мысли, в контексте которой жизнь предстает “серией несвязанных между собой эпизодов" и происходит “своего рода ликвидация Я” [18, с. 277]. Разделяя общий пафос построений Макинтайра, его понимание единства индивидуально-неповторимого и опыта коллективных практик в перспективе жизненного проекта личности, Рикёр констатирует принципиально герменевтический характер построения повествования идентичности как смысловой интерпретации единства целостности и частностей жизни. Конкретная история жизни автора повествования, как и любая история, должна опираться на различные фазисы интерпретации от опоры на свидетельства до понимания-объяснения и собственно повествования. Одновременно, в отличие от Макинтайра, им акцентируется роль воображения и постоянного эксперимента с собственным “Я” в свете экзистенциальной озабоченности субъекта, его постоянного самообнаружения между пространством опыта и горизонтом ожидания, открывающим будущее. “Вот почему, - заключает Рикёр, - не будет абсурдным говорить о нарративном единстве конкретной жизни - под знаком повествований, которые учат с помощью рассказа соединять прошлое и настоящее” [3, с. 197-198]. Дух эстетического эксперимен- та с собой, запечатлевающийся в повествовании о единстве собственной жизни, не снимает вопроса об обнаружении ее этических ориентиров.

В полемике с теориями, не видящими за конкретными актами деятельности целостности жизни, Рикёр вполне солидарен с Макинтайром в необходимости раскрыть этический потенциал наррации самоидентичности личности. Поскольку искусство рассказа, как подчеркивал В. Беньямин, содержит обмен опытом, оно представляется Рикёру, имманентно содержит в себе оценки действий позитивного и негативного плана, предполагающие телеологические и деонтологические основания. Даже мысленные опыты в лаборатории литературного воображения в целом предполагают отношение к добру и злу. Не безразлично к ним и историческое повествование. Когда же речь заходит о рассказе, излагающем ход собственной жизни, то избежать видения таковой в этической перспективе кажется Рикёру просто невозможным. Нарративная идентичность, опосредуя полюса характера и сохранения самости “Я", которая представляется Рикёру изначально этической. “Сохранение "Я-сам” для личности - это такой способ вести себя, чтобы другой мог на нее рассчитывать" [3, с. 200]. Этим предполагается ответственность “Я” перед “Другим". Повествование о себе имманентно содержит представление о предполагаемо истинной жизни и благе, апеллируя к значимым чертам “любимых и узнаваемых персонажей”. Вновь вступая в полемику с отрицанием личностной идентичности Парфитом, Рикёр утверждает, что ее присутствие в “нарративном единстве жизни” есть залог существования этики ответственности “Я” перед “Другим", чья значимость была продемонстрирована Ж. Набером, Г. Марселем и Э. Левинасом.

Видение нарративной самоидентичности личности, предложенное Рикёром, можно рассматривать как ответ на различные варианты объективистского рассмотрения личности и ее проявления в языковых актах, деятеля и действия в перспективе семантики и прагматики, сложившиеся в аналитической философии и приводящие к своеобразной ликвидации “Я” в реальности его уникального единства и становления во времени. Подмена конкретного единства созидающего себя личностного “Я”, нередуцируемого к частным свойствам и проявлениям, неприемлема для него в силу устойчивой персоналистической установки его творчества. Одновременно нельзя не заметить, что Рикёр плодотворно осваивает аппарат и стратегию ана- 


\section{Философия и культура 9(93) • 2015}

литической философии, полагая их значимыми для рационально-теоретического рассмотрения конкретного единства тождественности и самости личностного “Я”. Намеченная им программа синтеза аналитической философии и герменевтики оказывается вполне действенной и реализованной в подходе к проблеме нарративной идентичности как выражения единства жизни личности. Осуществленное им последовательное круговое герменевтическое движение от аналитики семантики и прагматики личности и ее коммуникативных актов, деятеля и действия к постижению способа синтетического объединения тождественности и самости “Я” в рассказе о себе оказывается поэтому достаточно теоретически обоснованным и убедительным. Желание обрести синтетический способ объединения строгости англо-американской аналитики и платформы феноменологии и герменевтики в финальной инстанции не отменяет общей устремленности его построений к постижению этико-морального и рефлексивно-метафизического горизонта рассказа о единстве собственной жизни. Стратегия размышлений Рикёра о нарративной самоидентичности личности оказывается весьма симптоматичной в плане современного взаимного сближения способов философствования, характерных для англо-американской и континентальной европейской традиций.

\section{Список литературы:}

1. Гуревич П.С. Проблема целостности человека. М.: ИФ РАН, 2004. 178 с.

2. Вдовина И.С. Феноменология во Франции. М.: Канон + РООИ "Реабилитация", 2009. 400 с.

3. Рикёр П. Я - сам как другой. М.: Изд-во гуманитарной литературы, 2008. 416 с.

4. Strawson P.F. Individuals. An Essay of Descriptive Metaphysics. L.-N.Y: Routledge, 1996. 260 p.

5. Austin J.J. How to do Things with Words. Cambridge: Cambridge University Press, 1975. 192 p.

6. Searle J.R. Intentionality. Cambridge: Cambridge University Press, 1995. 281 p.

7. Ricoeur P. Hermeneutics and the Human Sciences. Cambridge: Cambridge University Press, 1981. 314 p.

8. Ricoeur P. From Text to Action. N.Y.: State University of New York Press, Albany, 2008. 262 p.

9. Danto A.C. Analytical Philosophy of Action. Cambridge: Cambridge University Press, 1973. 226 p.

10. Кант И. Критика чистого разума // Кант И. Собр. соч. в 6-ти тт. Т. 3. М.: Мысль, 1964. 799 с.

11. Ricoeur P. Temps et récit III. Le temps raconté. Paris: Points Essais, 1985. 404 p.

12. Ricoeur P. Freedom and Nature: The Voluntary and The Involuntary. Evanston: Northwestern University Press, 1987.498 p.

13. Райл Г. Понятие сознания. М.: Идея-Пресс, Дом интеллектуальной книги, 1999. 408 с.

14. Рикёр П. Память, история, забвение. М.: Изд-во гуманитарной литературы, 2004. 728 с.

15. Parfit D. Reasons and Persons. Oxford: Oxford University Press, 1986. 560 p.

16. Рикёр П. Время и рассказ. Т. 1. М.; СПб.: ЦГНИИ ИНИОН РАН: Культурная инициатива: Университетская книга, 2000. 313 c.

17. Kermode F. Genesis of Secrecy, on the Interpretation of Narrative. Cambridge: Cambridge University Press, 1979.196 p.

18. Макинтайр А. После добродетели. М.: Академический проект, 2000. 384 c.

\section{References (transliteration):}

1. Gurevich P.S. Problema tselostnosti cheloveka. M.: IF RAN, 2004. 178 s.

2. Vdovina I.S. Fenomenologiya vo Frantsii. M.: Kanon + ROOI "Reabilitatsiya", 2009. 400 s.

3. Riker P. Ya - sam kak drugoi. M.: Izd-vo gumanitarnoi literatury, 2008. $416 \mathrm{~s}$.

4. Strawson P.F. Individuals. An Essay of Descriptive Metaphysics. L.-N.Y: Routledge, 1996. 260 p.

5. Austin J.J. How to do Things with Words. Cambridge: Cambridge University Press, 1975. 192 p.

6. Searle J.R. Intentionality. Cambridge: Cambridge University Press, 1995. 281 p.

7. Ricoeur P. Hermeneutics and the Human Sciences. Cambridge: Cambridge University Press, 1981. 314 p.

8. Ricoeur P. From Text to Action. N.Y.: State University of New York Press, Albany, 2008. 262 p.

9. Danto A.C. Analytical Philosophy of Action. Cambridge: Cambridge University Press, 1973. 226 p.

10. Kant I. Kritika chistogo razuma // Kant I. Sobr. soch. v 6-ti tt. T. 3. M.: Mysl', 1964. 799 c.

11. Ricoeur P. Temps et récit III. Le temps raconté. Paris: Points Essais, 1985. 404 p.

12. Ricoeur P. Freedom and Nature: The Voluntary and The Involuntary. Evanston: Northwestern University Press, 1987.498 p.

13. Rail G. Ponyatie soznaniya. M.: Ideya-Press, Dom intellektual'noi knigi, 1999. 408 s.

14. Riker P. Pamyat', istoriya, zabvenie. M.: Izd-vo gumanitarnoi literatury, 2004. 728 s.

15. Parfit D. Reasons and Persons. Oxford: Oxford University Press, 1986. 560 p.

16. Riker P. Vremya i rasskaz. T. 1. M.; SPb.: TsGNII INION RAN: Kul'turnaya initsiativa: Universitetskaya kniga, 2000.313 s.

17. Kermode F. Genesis of Secrecy, on the Interpretation of Narrative. Cambridge: Cambridge University Press, 1979.196 p.

18. Makintair A. Posle dobrodeteli. M.: Akademicheskii proekt, 2000. 384 s. 